\title{
Working from home in Romania during COVID-19 lockdown across occupations and economic sectors
}

\author{
Adina-Maria Iorganda ${ }^{1}$ and Mihaela Matei $^{2}$ \\ 1) 2) The Bucharest University of Economic Studies, Bucharest, Romania. \\ E-mail: adinamvoda@yahoo.co.uk; E-mail: mihaela.matei16@politice.ro
}

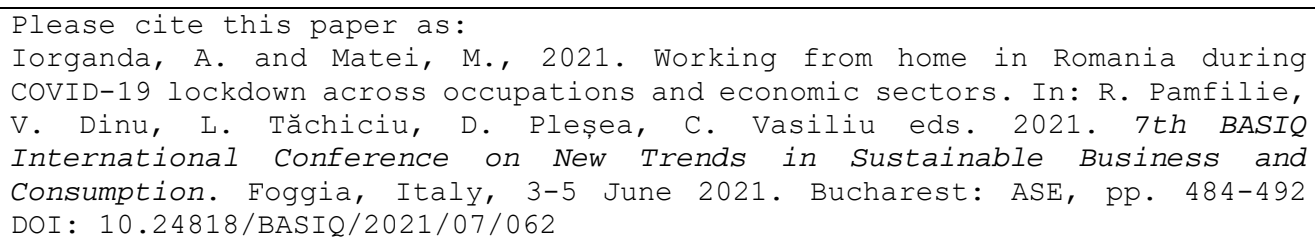

\begin{abstract}
Based on novel household data, we document the status of working from home in Romania during the 2020 COVID-19 pandemic. Remote work had a sharp increase during the lockdown, showcasing significant differences among different categories of workers' behaviours, pointing to a gendered nature of the practice.

The article is built on the data resulting from a Household Survey distributed on random sampling by the World Bank in Romania at the level of 2,241 households, covering approximately 5,700 individuals.

We have found out that women working remotely were more numerous than men. Moreover, amenable occupations to working from home appear to belong to the specialist, clerks, and skilled and assimilated workers, whereas managers have worked from home to a lesser extent than expected. Finally, the highest numbers of employees working from home were in the education sector, followed by employees in other public, social and personal services and financial intermediation. Remote work in the public administration was modest.

The findings of this research are useful for both companies and public administration representatives. Companies in specific economic sectors that plan to transition into working from home can become aware of their potential remote work by learning from peers. Therefore, they could search for streamlining their organizational processes to allow work from home gradually, which could generate reduced administrative costs, high returns for the environment and better work-life balance for the employees. Public administration may challenge their current practices to increase the share of employees working from home, as we have documented that there is an unexplored potential for remote work in the public sector.
\end{abstract}

\section{Keywords}

work from home, remote work, telecommuting, occupations, labour market

DOI: 10.24818/BASIQ/2021/07/062

\section{Introduction}

In Romania, working from home became highly popular only because of the Covid-19 pandemic, as the Romanian Government highly recommended it to promote social distancing. As in other countries all over the world, the Covid-19 pandemic came as a shock, leaving companies across various industries with three options: (i) closing the business completely, (ii) continue business as always with the corresponding healthy risk for the employees or (iii) moving into remote work (Bartik, et all., 2020). The last option was enforced despite the limited existence of procedures regulating remote work and despite the employer's resistance towards reduced control over the activity of their employees. Because 
of the pandemic's rapid spread, all employees who could work from home had to work from home in March 2020 during the lockdown.

Using evidence and theory (Karanikas and Cauchi, 2020), we believe that understanding the remote work phenomenon is a first step towards fostering these transitions in Romania, considering Romania is and used to rank before the pandemic on the last places in the European Union (EU) in the number of employees working from home.

Working remotely was not common in Romania before the pandemic (Iorganda and Roman, 2020). According to Romanian legislation, working from home has two forms: teleworking (working from any place, including home, through telecommunication devices) and working exclusively at home (e.g., making candles). Teleworking is the dominant form of remote work in Romania. The legislation on teleworking was approached in Romania in three stages. The first stage was prior to 2018 when Law number 81/2018 regulates teleworking activity. At this stage, Romanian employees had one of the lowest percentages of remote work in the EU, 0.4\% (Eurostat, 2017). Until 2018, the Romanian legislation was among the fewest in the EU with no provisions regarding teleworking (not even at the level of the collective labour agreements).

In the second stage, Law number 81/2018 regarding teleworking activities was adopted, and the number of employees working from home increased to $0.8 \%$ in 2018 and $1,4 \%$ in 2019 . The law was drafted following the lobby of employees in the IT sector, considering the labour shortages in the field and the necessity to regulate the practice of some international companies that already allowed employees to work remotely. It is a well-known fact that remote work is performed in Romania predominantly by international corporate companies in big cities. Because of their foreign management, corporate companies are more open to transferring international practices regarding remote work to their Romanian branches.

Nevertheless, despite a consistent increase in the number of employees adopting this practice, Romania was still ranking in the last places in the European Union (before Bulgaria) regarding the number of employees working from home in 2019 (Eurostat, 2019).

The third stage of transition towards remote work started in 2020. The Romanian Covid-19 pandemic lockdown was one of the most restrictive in the world as going outside the house was forbidden (a specific declaration paper was required), except for labour, medical, or limited shopping purposes. Consequently, working from home became a new norm that forced all public and private organizations to change their practices. Moreover, to stimulate teleworking activities, the Romanian Government provided a one-off stimulus package (2,500 lei, approx. \$600) for employers to purchase necessary equipment that facilitates working from home for their employees. Moreover, 400 lei (approx. 100\$) can be deducted by the employers for the monthly expenditure of each employee working from home, starting 2021.

The sanitary restrictions implemented in the context of COVID-19 pandemic in Romania have generated an increase in stress, which affects different professional or social categories, including students ( Roman and Plopeanu, 2021) or refugees (Cimpoeru, et. al., 2020).

In this paper, we use the data provided by a WB household survey to inform the extent of remote work during the 2020 Covid-19 pandemic lockdown in Romania. The World Bank conducted the household survey in Romania in the last weeks of July/August 2020 and queries about the habit of working from home in March-May 2020, when the whole country was under complete lockdown restrictions.

The article provides interesting data about the job profile of Romanian employees working from home in Romania during the lockdown, facilitating a deeper understanding of the behaviours and contexts influencing this change in working habits. This behavioural change may provide potentially more stable perspectives for work arrangements in some occupations and businesses and not only a temporary response to the health crisis. We explore the wingspan of remote work in terms of gender and occupations of people working from home and across economic sectors. We talk briefly about the scaleup possibilities of remote work after the pandemic ends. 


\section{Review of the scientific literature}

There are some proven advantages of using flexible working arrangements with positive effects on administrative efficiency. For instance, some researchers point to the effects on long-term productivity of the company correlated with the temporal flexibility oriented on the employee, rather than on the organization as a whole (Eurofound, 2012). According to the International Labor Organization (ILO) (2019), available alternative working arrangements are also linked with organizations' efficiencies, reducing sick leave and paid absence and reducing absenteeism. Moreover, if managed properly, it can contribute to improved productivity and firm performance.

Telecommuting grew steadily both in popularity and uptake over the last years worldwide, and companies have been working over the years to improve the work packages of employees with telecommuting activities (Picu and Dinu, 2016).

In terms of gender, it appears that working from home is more appealing to men rather than women (Wheatley, 2017), as women prefer reduced working hours to care for household responsibilities. This seems to be the case at the European level as in 2019, male employees who sometimes worked from home $(9.3 \%)$ outnumber female employees $(8.6 \%)$ (Eurostat, 2019). However, this aspect is reversed in employees usually working from home, as women are more prone to remote work $(5.7 \%)$ than men $(5.2 \%)$. Romania follows the same trend, as the number of women employees usually working from home $(1.1 \%)$ is almost double the number of men $(0.5)$, whereas the number of men sometimes working from home (0.6\%) is slightly higher than that of women (0.5\%) (Eurostat, 2019).

To further explore the extent of remote work in Romania, we build our analysis on the authors' previous research in the field (Iorganda and Roman, 2021), who theoretically assessed the applicability of working from home in Romania across occupations in the International Standard Classification of Occupations in Romania (COR). They conclude that almost $46 \%$ of occupations in Romania can be performed totally or partially from home, especially in the following occupational groups: professionals, managers, technical, and associate professionals.

The potential of home-based work to continue after the Covid pandemic depends on a number of factors, such as business conditions at the industry level and labour demand (Bick, Blandin, and Mertens, 2020).

\section{Research methodology}

This study investigates the relationship between the COVID-19 pandemic and the changes in work arrangements, based on descriptive analysis. Higher levels of remote work for many employees are hypothesized. Since the study evaluates the WFH, teleworking, telecommuting, e-working, flexible workplace, and remote work in the COVID-19 context, we used quantitative methods of analysis.

For the researched we have used the results of the Household Pulse Survey (HPS) carried out during the lockdown in Romania, among a sample of the 2,600 employees, representative for the Romanian adult population in terms of age, gender, occupation and population in the area of residence.

The Household Pulse Survey provides data to help understand the experiences of Romanian households during the coronavirus pandemic. The survey asks questions about how employees have been affected by the ongoing crisis. Data collection of the HPS began on July 2021 and ended in August 2021. World Bank developed technical documentation of the survey in Romania.

The HPS sampling frame consisted of housing units where at least one cell phone number was known. The survey recruits 5,700 participants, estimating that the employees' amount $(2,630)$ would detect differences in work arrangements individually (remote work, teleworking, and flexible work arrangements) during the COVID-19 pandemic in Romania.

Employees were selected as the aim of this study was to examine how the COVID-19 crisis fed into the employment of household members and behaviors, the differential impact of the COVID-19 outbreak on employees work arrangements, and to capture if the worker was able to work from home (home-based work) during the lockdown, whether they had to work from somewhere else (office, shop, hospital), or whether they were unable to work at all (in which record they may have stopped working). 
The HPS produces pandemic impact estimates using the answers from responding persons. It is important to consider possible availability biases: it is possible that the estimates may be biased if answers from respondents differ from the potential answers of nonrespondents. Due to the sampling procedure, although many respondents were involved, we cannot confirm that the data is representative of the general population of Romania.

We supplement these findings with the statistical data provided by Eurostat on the percentage of employed persons working at home (lfsa ehomp) and persons doing online training courses (isoc_ci_ac_i), as well as findings from the Eurofound survey (2020). To extract and interpret the raw data for the analysis, STATA software was used.

\section{Results and discussion}

\section{The extend of working from home in Romania}

During the 2020 lockdown in Romania, the remote work is still modest, as only $22 \%$ of the interviews declared having worked from home in May 2020. When compared with the EU average of $37 \%$ (Eurofound, 2020), we observe that the situation did not improve overall. Moreover, the WB survey findings show that more Romanians work from home than estimated (18.4) by the Eurofound survey (Eurofound, 2020). As presented in Table no.1 below, out of 2,637 respondents, 576 (22\%) were working from home during the 2020 Covid-19 lockdown, 638 (24\%) were not working at all, while the great majority of respondents still worked from the office $(54 \%)$.

Table no. 1. Working from home during Covid lockdown across gender

\begin{tabular}{lcccc}
\hline & WfH & Not $\mathbf{W f H}$ & Not working at all & Total \\
\hline Gender & & & 345 & 1,432 \\
Male & 230 & 857 & 293 & 1,205 \\
Female & 346 & 566 & $\mathbf{6 3 8}$ & $\mathbf{2 , 6 3 7}$ \\
Total & $\mathbf{5 7 6}$ & $\mathbf{1 , 4 2 3}$ & Source: Authors' elaboration
\end{tabular}

Source: Authors' elaboration

The female workers dominated the batch of employees working from home, with $60 \%$ of women working from home. The situation could be explained by the dominant figure of women within the household, thus creating pressure on employers to allow women to telework while taking care of small children. Additionally, the education sector, where women employees are predominant, has the highest number of employees into forced remote work as all schools in the country went online.

\section{The spread of employees working from home across occupations and economic sectors}

The occupations that count the highest number of employees working from home are the professionals $(40 \%)$, the clerks $(13.89 \%)$, the skilled and assimilated workers $(8.85)$, the service and trade workers $(8.33 \%)$, and the elementary occupations $(7.64 \%)$. As observed in Table number 2 below, female workers are most prone to work from home across various occupations. However, it is interesting to notice that this trend is reversed in the case of skilled and assimilated workers, where men appear more prone to remote work than women. Plant and machine operators $(1,22 \%)$ and armed forces personnel were the last to work from home $(0.69 \%)$ due to their work profile, requiring specific interaction with different types of machinery that cannot be controlled remotely and need immediate intervention (if the case). 
Table no. 2. Working from home during Covid lockdown across occupations

\begin{tabular}{|c|c|c|c|c|}
\hline \multirow[t]{2}{*}{ Occupations } & \multirow{2}{*}{$\begin{array}{l}\text { NACE } \\
\text { code }\end{array}$} & \multicolumn{2}{|c|}{ Gender } & \multirow[t]{2}{*}{ Total } \\
\hline & & Male & Female & \\
\hline \multirow[t]{2}{*}{ Specialist in various fields of activity } & 2 & 74 & 160 & 234 \\
\hline & & 32.17 & 46.24 & 40.63 \\
\hline \multirow[t]{2}{*}{ Clerks } & 4 & 29 & 51 & 80 \\
\hline & & 12.61 & 14.74 & 13.89 \\
\hline \multirow[t]{2}{*}{ Skilled and assimilated workers } & 7 & 29 & 22 & 51 \\
\hline & & 12.61 & 6.36 & 8.85 \\
\hline \multirow[t]{2}{*}{ Service and trade worker } & 5 & 18 & 30 & 48 \\
\hline & & 7.83 & 8.67 & 8.33 \\
\hline \multirow[t]{2}{*}{ Elementary occupation } & 9 & 13 & 31 & 44 \\
\hline & & 5.65 & 8.96 & 7.64 \\
\hline \multirow{2}{*}{$\begin{array}{l}\text { Technician or specialist in the technical } \\
\text { field }\end{array}$} & 3 & 22 & 17 & 39 \\
\hline & & 9.57 & 4.91 & 6.77 \\
\hline \multirow{2}{*}{$\begin{array}{l}\text { Skilled worker in agriculture, forestry, } \\
\text { and fishing }\end{array}$} & 6 & 23 & 15 & 38 \\
\hline & & 10 & 4.34 & 6.6 \\
\hline \multirow[t]{2}{*}{ Legislator, senior official, or director } & 1 & 14 & 17 & 31 \\
\hline & & 6.09 & 4.91 & 5.38 \\
\hline \multirow{2}{*}{$\begin{array}{l}\text { Plant and machine operators, machine } \\
\text { and equipment assemblers }\end{array}$} & 8 & 5 & 2 & 7 \\
\hline & & 2.17 & 0.58 & 1.22 \\
\hline \multirow[t]{2}{*}{ Armed forces } & 10 & 3 & 1 & 4 \\
\hline & & 1.3 & 0.29 & 0.69 \\
\hline \multirow[t]{2}{*}{ Total: } & & 230 & 346 & 576 \\
\hline & & 100 & 100 & 100 \\
\hline
\end{tabular}

Source: Authors' analysis

An interesting aspect emerging from the analysis is that employees in elementary occupations (7.64) appear to have worked from home more than employees in managerial occupations $(5,38 \%)$ during the pandemic. This aspect suggests that management occupations have not reached their potential in terms of amenability of working from home, especially because management activities corresponding to managerial occupations are more amenable to (tele)working than elementary occupations, that usually involve face to face interaction or manual handling of specific objects (Iorganda and Roman, 2020). The situation has some potential explanations. A possible reason for the low number of managers not working remotely is the lack of willingness to give up the control manifested through their physical presence in the workplace. This could reflect the manager's lack of control and mistrust in the employee's capacities to perform, especially during a crisis. For example, it was observed empirically that during the Covid-18 lockdown, managers in various economic activities, including in the public administration, preferred to be on the office premises most of the time. 


\begin{tabular}{|c|c|c|c|c|}
\hline \multicolumn{5}{|c|}{ New Trends in Sustainable Business and Consumption } \\
\hline \multicolumn{5}{|c|}{ Table no. 3. Working from home during Covid lockdown across economic sectors } \\
\hline \multirow[t]{2}{*}{ Economic sector } & \multirow[t]{2}{*}{ Code } & \multicolumn{2}{|c|}{ Gender } & \multirow[t]{2}{*}{ Total } \\
\hline & & Male & Female & \\
\hline \multirow[t]{2}{*}{ Education } & 12 & 45 & 126 & 171 \\
\hline & & 19.57 & 36.42 & 29.69 \\
\hline \multirow{2}{*}{$\begin{array}{l}\text { Other public, social and personal } \\
\text { services }\end{array}$} & 14 & 42 & 58 & 100 \\
\hline & & 18.26 & 16.76 & 17.36 \\
\hline \multirow[t]{2}{*}{ Financial intermediation } & 9 & 25 & 42 & 67 \\
\hline & & 10.87 & 12.14 & 11.63 \\
\hline \multirow{2}{*}{$\begin{array}{l}\text { Transport, storage, and } \\
\text { communications }\end{array}$} & 8 & 28 & 19 & 47 \\
\hline & & 12.17 & 5.49 & 8.16 \\
\hline \multirow[t]{2}{*}{ Wholesale and retail trade } & 6 & 15 & 22 & 37 \\
\hline & & 6.52 & 6.36 & 6.42 \\
\hline \multirow[t]{2}{*}{ Manufacturing } & 3 & 14 & 18 & 32 \\
\hline & & 6.09 & 5.2 & 5.56 \\
\hline \multirow{2}{*}{$\begin{array}{l}\text { Real estate, rental, and } \\
\text { commercial activities }\end{array}$} & 10 & 14 & 11 & 25 \\
\hline & & 6.09 & 3.18 & 4.34 \\
\hline \multirow[t]{2}{*}{ Agriculture, forestry, and fishing } & 1 & 13 & 10 & 23 \\
\hline & & 5.65 & 2.89 & 3.99 \\
\hline \multirow[t]{2}{*}{ Public administration and defense } & 11 & 10 & 13 & 23 \\
\hline & & 4.35 & 3.76 & 3.99 \\
\hline \multirow[t]{2}{*}{ Health and social work activities } & 13 & 6 & 15 & 21 \\
\hline & & 2.61 & 4.34 & 3.65 \\
\hline \multirow[t]{2}{*}{ Construction } & 5 & 9 & 3 & 12 \\
\hline & & 3.91 & 0.87 & 2.08 \\
\hline \multirow[t]{2}{*}{ Hotels and restaurants } & 7 & 5 & 6 & 11 \\
\hline & & 2.17 & 1.73 & 1.91 \\
\hline \multirow{2}{*}{$\begin{array}{l}\text { Supply of electricity, gas, and } \\
\text { water }\end{array}$} & 4 & 4 & 0 & 4 \\
\hline & & 1.74 & 0 & 0.69 \\
\hline \multirow[t]{2}{*}{ Mining and quarrying } & 2 & 0 & 3 & 3 \\
\hline & & 0 & 0.87 & 0.52 \\
\hline \multirow[t]{2}{*}{ Total } & & 230 & 346 & 576 \\
\hline & & 100 & 100 & 100 \\
\hline
\end{tabular}

Source: Authors' analysis

As expected in this context, the share of employees in the education sector that have worked from home during the first lockdown (especially women) is the highest (see Table no. 3). This is explained by the closure of all schools throughout the country and the urgency to move into remote work. Remote education is atypical and negatively impacts the learning outcomes, especially for young elementary students, so this situation is not expected to continue after the pandemic ends. However, forced remote learning might be conducive towards more sustainable practices of remote learning, including at the firm level, as the offers for online training increased. For instance, during the pandemic, the Romanian 
Govern amended the law to allow all training providers to switch to online training, where possible. At the European level, forced transition into working from home appears to have stimulated online learning, as more people got involved in learning activities. During 2019-2020, participation in online training activities increased by $4 \%$, from $8 \%$ in 2019 to $12 \%$ in 2020 (Eurostat, 2020). At the international level, during the pandemic, Coursera developed a worldwide partnership to reskill employees with more than 100 Governments.

The analysis showed (see Table no. 3 above) that working from home was prevalent in the financial intermediation (11.63), the transport (8.16), and the wholesale and retail trade (6.42) economic sectors. Employees in public administration and defense were among the last categories to work from home (3.99), ranking approximately in the same position as employees in health and social work activities (3.65\%) who carried the burden of the pandemic and little above employees in construction (2.08). Women have worked from home more than men during the lockdown across all economic activities, except those traditionally performed by men, such as transportation, real estate, agriculture, and construction.

The reduced number of individuals working from home in the Romanian public administration could be explained by the resistance to change and the managers' reluctance to losing control over employee's activities. Moreover, remote work was limitedly used in the public administration before the pandemic. However, the Covid-19 pandemic accelerated the change. Because of the lockdown, the Ministry of Labour in Romania urgently issued a set of criteria to facilitate working from home. One of the most important criteria to be allowed to WFH was to have children under care and suffer from chronic disease. According to a recent survey conducted by the National Administration Institute (2020) in Romania, $49 \%$ of management staff and $62 \%$ of execution staff have worked from home during the pandemic, and this appears to be a new experience for them (only $2 \%$ used teleworking before the pandemic).

\section{Conclusions}

Remote work is a sustainable work practice that has been highly encouraged in Romania because of the pandemic while forcing various economic sectors to change. Even though Romania is still in the last place in Europe regarding remote work, our analysis shows that an important shift towards this practice was initiated, and there is also room for improvement. We have observed that women are more prone to working from home than men. Moreover, employers in education, financial intermediation, and transport sectors shift more rapidly into remote work than employers in public administration. Also, we observed that employees in managerial occupations such as legislators, senior officials or directors were less amenable to working from home than employees in elementary occupations. Furthermore, we believe that enforced telework practices will probably continue after the pandemic ends, considering the experience gained by employers, HR managers, and employees in the field.

In a nutshell, working from home has various benefits: (i) reduced administrative costs for the companies, (ii) a better work-life balance for the employees, and (iii) reduced carbon emission due to reduction in commuting for the government decarbonization objectives (The European Green Deal, 2019). The analysis findings have significant practical implications in terms of economic activities and sectors that the Government can further support to increase the uptake of the working from home practices. On the one hand, managers can be encouraged to give more autonomy to employees and lead by the power of example, working from home to a more significant extent than in the past. Equally, public administration decision-makers can further reform their practices to encourage a large-scale uptake of working from home at the level of the employees. Last but not least, the Governmental support for stimulating remote work should be continued, permanently evaluated and directed towards the economic sectors that are more amenable towards working from home. The Public Administration sector must be purposefully reformed to increase the remote work uptake.

\section{Acknowledgements}

The authors would like to thank Reena C Badiani-Magnusson, Senior Economist in the World Bank, for kindly sharing the microdata from the Household Pulse Survey for this analysis. 


\section{References}

Alexander, B., Blandin, A. and Mertens, K., 2020. Work from Home After the COVID-19 Outbreak, [online] Available at: <from https://www.dallasfed.org//media/documents/research/papers/2020/wp2017.pdf $>$ [Accessed 17 September 2020].

Bartik, A., Cullen Z., Glaeser, E., Luca, M., and Stanton, C., 2020. What Jobs are Being Done at Home During the Covid-19 Crisis? Evidence from Firm-Level Surveys, [online] Available at: $<$ https://www.nber.org/papers/w27422 > [Accessed 10 March 2021].

Bick, A., Blandin, A., and Mertens, K., 2020. Work from Home Before and after the Covid-19 Outbreak. [online] CEPR Discussion Paper No. DP15000, Available at: $<$ https://ssrn.com/abstract $=3650114>$ [Accessed 10 March 2021].

Cimpoeru, S., Roman, M., Kobeissi, A. and Mohammad, H., 2020. How are European Migrants from the MENA Countries Affected by COVID-19? Insights from an Online Survey. Journal of Social and Economic Statistics, 9(1), pp.128-143.

Dingel, J. and Neiman, B., 2020. How Many Jobs Can be Done at Home? Covid Economics: Vetted and Real-Time Papers. [pdf] Available at: < https://bfi.uchicago.edu/wpcontent/uploads/BFI_White-Paper_Dingel_Neiman_3.2020.pdf $>$ [Accessed 10 March 2021].

Eurofound, 2012. Organisation of working time: Implications for productivity and working conditions, [pdf] Available at:

$<$ https://www.eurofound.europa.eu/sites/default/files/ef_files/pubdocs/2012/50/en/2/EF1250EN.p df $>$ [Accessed 10 March 2020].

Eurofound, 2020. Living, working and COVID-19: First findings - April 2020, [online] Available at: $<$ https://www.eurofound.europa.eu/publications/report/2020/living-working-and-covid-19firstfindings-april-2020> [Accessed 12 March 2021].

European Commission, 2019. Communication from the Commission to the European Parliament, the European Council, the Council, the European Economic and Social Committee and the Committee of the Regions the European Green Deal, [online] Available at: <https://eurlex.europa.eu/resource.html?uri=cellar:b828d165-1c22-11ea-8c1f-

01aa75ed71a1.0002.02/DOC_2\&format=PDF> [Accessed 12 March 2021].

EUROSTAT, 2019. Database on employed persons working from home, [online] Available at: $<$ https://appsso.eurostat.ec.europa.eu/nui/show.do?dataset=lfsa_ehomp $>$ [Accessed 10 March 2021].

EUROSTAT, 2019. Database on Internet use for online courses, [online] Available at: $<$ http://appsso.eurostat.ec.europa.eu/nui/show.do?query=BOOKMARK_DS-053730_QID_140ED59C_UID_-

3F171EB0\&layout=INDIC_IS,L,X,0;TIME,C,X,1;GEO,L,Y,0;UNIT,L,Z,0;IND_TYPE,L,Z,1;IN DICATORS,C,Z,2;\&zSelection=DS-053730INDICATORS,OBS FLAG;DS053730UNIT,PC_IND;DS-053730IND_TYPE,IND_TOTAL;\&rankName1=UNIT_1_2_1_2\&rankName2=INDICATORS_1_2_-1_2\&rankName3=IND-TYPE_1_2_-

$1 \_2 \&$ rankName4=INDIC-

IS_1_2_0_0\&rankName5=TIME_1_1_1_0\&rankName6=GEO_1_2_0_1\&rStp $=\& \mathrm{cStp}=\& \mathrm{rDCh}=$

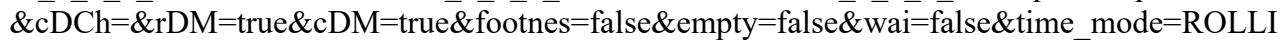
NG\&time_most_recent $=$ true\&lang $=\mathrm{EN} \& \mathrm{cfo}=\% 23 \% 23 \% 23 \% 2 \mathrm{C} \% 23 \% 23 \% 23 . \% 23 \% 23 \% 23>$ [Accessed 10 March 2021].

Iorganda, A.M. and Roman, M., 2020. Work from home by occupation in Romania: Initial assessment in the context of Covid-19 pandemic, [online] Proceedings of the 14th International Management Conference "Managing Sustainable Organizations", Nov. 2020, Bucharest, Romania, pp.811-820. 
Available at: <http://conferinta.management.ase.ro/archives/2020/PDF/4_12.pdf $>$ [Accessed 10 March 2020].

Karanikas, N., and Cauchi, J., 2020. Literature review on parameters related to Work-From-Home (WFH) arrangements. [pdf] Available at: $<$ https://eprints.qut.edu.au/205308/1/QUT_Report_WFH_parameters.pdf> [Accessed 10 March 2020].

National Institute for Administration, 2020. Study on the opportunity of introducing flexible working ways within the Romanian public administration. [pdf] Available at: <http://ina.gov.ro/wpcontent/uploads/2021/01/STUDIU-moduri-de-lucru-flexibile.pdf> [Accessed 10 March 2020].

Picu, C.G. and Dinu, A., 2016. Research on the Current Telecommuting Trends in United States and European Union Markets. Bucharest. Management and Economics Review, 1(2), pp.194-202.

Roman, M. and Plopeanu, A.P., 2021. The effectiveness of the emergency eLearning during COVID19 pandemic. The case of higher education in economics in Romania. International Review of Economics Education, 37, Article number: 100218.

International Labor Organization, 2019. Telework in the 21st century: an evolutionary perspective, [online] Available at: $<$ https://www.elgaronline.com/view/edcoll/9781789903744/9781789903744.xml> [Accessed 12 March 2021].

Wheatley, D., 2017. Employee satisfaction and use of flexible working arrangements. Work, Employment and Society, 31(4), pp.567-585. 